\title{
Distribution of pathogenic yeasts and humoral antibodies to candida among hospital inpatients
}

\author{
FC ODDS* AND EGV EVANS $\dagger$ \\ From the *Department of Microbiology, University of Leicester, and the $†$ Mycology Unit, University \\ Department of Microbiology and Dermatology, General Infirmary, Leeds, UK
}

SUMMARY The frequencies of the carriage of yeast pathogens and of serum precipitins to a variety of candida antigens among 254 patients generally tended to increase with the length of the patient's stay in hospital. This trend was observed even though none of the patients investigated showed signs or symptoms of superficial or systemic candidosis.

The extent of the general trend varied considerably between subgroups of patients within the general categories of 'surgical' and 'nonsurgical' inpatients. Increases in both frequencies and quantities of yeasts in the mouth were most evident postoperatively among patients who underwent open-heart surgery and among nonsurgical patients who received antibiotics or steroids in hospital. The frequency of precipitins to Candida albicans cytoplasmic antigens in the absence of candidosis rose overall from $11 \%$ of 217 sera obtained within 24 hours of admission to $35 \%$ of 85 sera obtained five to 11 days after admission or operation. These 'false positive' antibodies were thought to arise after transient yeast overgrowth in the gut at the time of an acute illness or immediately after surgery.

The study adds further data to documented examples of 'false positive' candida antibodies and indicates the need for care in the diagnostic interpretation of candida precipitin test results among groups of patients at risk of yeast overgrowth during their hospital stay.

Systemic forms of candidosis appear most frequently as opportunistic infections among hospital inpatients. The problems associated with the diagnosis and treatment of these serious infections is well documented. ${ }^{12}$ Candidosis is regarded as an endogenous infection, and Candida spp, in particular Candida albicans, are frequently found as commensals of the digestive tract of normal individuals. The prevalence of these yeasts is thought to be higher among hospital inpatients than in the general population..$^{3-5}$ Several factors are said to predispose patients to yeast overgrowth and to systemic infection. The most well known of these are antibacterial therapy, steroid therapy, trauma, and surgical stress. ${ }^{6-8}$ There have been numerous studies on the occurrence of yeasts among particular types of 'at risk' hospital inpatients but few attempts to monitor quantitatively the effect of various medical and surgical therapies on the distribution of yeasts among a wide variety of patients in one hospital. Such a survey would reveal yeast distribution patterns that would enable potential reservoirs for endogenous infection to be

Received for publication 4 February 1980 identified and eliminated, where necessary, with prophylactic antifungal therapy.

The diagnosis of systemic candidosis is beset with difficulties. Isolation of yeasts from clinical material is not per se evidence of deep-seated infection; conversely, it can be difficult to recover the organism even from blood cultures in infected individuals. ${ }^{2}$ The detection of precipitating antibodies to cytoplasmic extracts of Candida spp is an aid to diagnosis of infection. Initially, the precipitin test was found to be both sensitive and specific when cytoplasmic antigens of $C$. albicans were used as test reagents. ${ }^{9}$ However, several recent studies have shown that precipitins to candida cytoplasmic antigens may be detected in the absence of overt candidosis in patients with chronic bronchitis, ${ }^{10}$ pregnant women, ${ }^{11-13}$ burn patients, ${ }^{14}$ patients with malignancies, ${ }^{15}$ and patients who have undergone heart surgery. ${ }^{12} 16-20$ In heart surgery patients there is evidence that the appearance of precipitins is related to an overgrowth of candida in the patient's digestive tract. 20

The present study was undertaken to determine the prevalence of yeast pathogens and precipitating 
antibodies to different yeast antigenic extracts among hospital inpatients grouped according to their illness or the nature of their treatment. This was done in order to determine which categories of patients are most susceptible to yeast overgrowth during their hospital stay and to assess further the value and significance of the precipitin test as an aid to diagnosis of deep-seated candida infections.

\section{Patients and methods}

The 254 patients included in this study were inpatients at the General Infirmary, Leeds. They were divided into two main categories, surgical and nonsurgical, and then assigned to subgroups according to their illness and/or the treatment they received. The groups were as follows:

\section{SURGICAL PATIENTS}

\section{Group 1 General surgery only}

Fifty-two patients were attending for abdominal surgery, radical mastectomy, or thyroidectomy (Table 1). Patients were admitted one to three days before operation and were usually discharged within two weeks of operation. This group included no diabetics or patients treated with antibiotics or steroids.

Table 1 Clinical details of surgical patients

\begin{tabular}{lll}
\hline Procedure & \multicolumn{2}{l}{ No. of patients } \\
\cline { 2 - 3 } & Group 1* & Group 2* \\
\hline Thyroidectomy & 6 & 1 \\
Radical mastectomy & 7 & 1 \\
Vagotomy & 9 & 4 \\
Cholecystectomy & 17 & 3 \\
Other abdominal surgery & 13 & 6 \\
Total & 52 & 15 \\
\hline
\end{tabular}

*Group 1 Patients with no factors predisposing to candidosis.

*Group 2 Patients treated postoperatively with systemic antibiotics.

\section{Group 2 General surgery/antibiotics}

Fifteen patients were admitted for similar procedures to those of the patients in group 1 (Table 1) but were treated with antibacterial antibiotics (usually tetracyclines or ampicillin) during the postoperative period. These patients were usually discharged within two weeks of operation.

\section{Group 3 Heart surgery}

Forty-four patients attended primarily for heart valve replacement with prostheses, homografts, or heterografts. The patients were admitted four to six days before surgery and given routine antifungal prophylaxis (amphotericin B lozenges, $10 \mathrm{mg}$, six times daily) throughout the preoperative period. Postoperatively, patients were kept for two to four days in the intensive care unit and then returned to the main thoracic ward where antifungal prophylaxis continued for a further seven to $\mathbf{1 0}$ days. In addition, patients were given ampicillin and cloxacillin prophylactically for 36 hours, starting 12 hours preoperatively. Patients were usually discharged two to four weeks after surgery.

\section{NONSURGICAL PATIENTS}

\section{Group 4 General medical}

The 59 patients in this group were all acute admissions (Table 2). None was a diabetic and none had received systemic antibiotic or steroid treatment. The average length of hospital stay was nine days.

Table 2 Clinical details of nonsurgical patients

\begin{tabular}{lccc}
\hline Diagnosis on admission & \multicolumn{2}{l}{ No. of patients } \\
\cline { 2 - 4 } & Group 4* & Group 5* & Group 6* \\
\hline Leukaemia & 4 & 3 & 7 \\
Other neoplastic disease & 2 & 0 & 1 \\
Rheumatoid arthritis & 0 & 1 & 2 \\
Obstructive airways disease & 2 & 8 & 4 \\
Cardiac disease & 29 & 3 & 0 \\
Other acute chest disease & 13 & 9 & 3 \\
Hepatic disease & 3 & 0 & 0 \\
Acute abdomen & 0 & 1 & 0 \\
Viral infection & 0 & 1 & 1 \\
Bacterial infection & 0 & 5 & 0 \\
Miscellaneous other diseases & 6 & 2 & 1 \\
Total & 59 & 33 & 19 \\
\hline
\end{tabular}

* Group 4 No factors predisposing to candidosis.

*Group 5 Treated systemically with antibiotics.

*Group 6 Treated systemically with corticosteroids.

\section{Group 5 Antibiotics}

These 33 patients were admitted to the same wards as those in group 4 (Table 2) but they received systemic antibacterial antibiotics (usually tetracyclines or ampicillin) starting at the time of admission. Their average length of hospital stay was nine days.

\section{Group 6 Steroids}

Nineteen patients were admitted to the same ward as those in group 4 (Table 2) but received systemic corticosteroid treatment from admission. Their average length of hospital stay was nine days.

\section{Group 7 Diabetic}

Thirty-two patients were admitted to the same wards as those in groups 4-6 but attended primarily for the stabilisation of their diabetes. Their average length of hospital stay was 13 days. 
INVESTIGATIONS

Cultures were taken from the mouth, rectum, and vagina, and a blood sample was collected for serological investigations within 24 hours of admission and at intervals during the patient's hospital stay.

\section{Culture}

Rectal and vaginal swabs were streaked on to plates of Sabouraud's dextrose agar (Difco) containing chloramphenicol $(50 \mathrm{mg} / \mathrm{l})$ to suppress bacterial growth. Mouths were sampled for yeasts by a mouthwash technique. Patients sucked $5 \mathrm{ml}$ of sterile water into their mouths through a sterile drinking straw. The patients were instructed to rinse the water around their mouths for approximately 10 seconds and then to return the water through the drinking straw into a sterile bottle; $0 \cdot 1 \mathrm{ml}$ portions of the mouthwash fluid were spread on to Sabouraud's agar (as above) with a sterile glass spreader. All specimens were processed within 1 hour of the sample time, and cultures were incubated at $37^{\circ} \mathrm{C}$ for 48 hours. Yeast colonies were counted and identified. Identification of $C$. albicans was based on a positive germ tube test. ${ }^{21}$ All germ tube negative yeasts were identified according to the criteria of Lodder. ${ }^{22}$

\section{Serological tests}

Serum samples were tested for the presence of candida precipitins by double diffusion (Ouchterlony) in agar. ${ }^{23}$ The sera were reacted against four antigen preparations: $C$. albicans and $C$. parapsilosis cytoplasmic extracts ( 1 and $10 \mathrm{mg} / \mathrm{ml}), C$. albicans culture filtrate $(2$ and $20 \mathrm{mg} / \mathrm{ml})$, and $C$. albicans mannan $(0.5$ and $5 \mathrm{mg} / \mathrm{ml}) .{ }^{23}$ The majority of serum samples reacted more strongly with the higher of the two concentrations selected for each antigen. However, in sera with relatively low antibody concentrations, reactions were noted only with the lower antigen concentrations. The presence of one or more precipitin lines to either or both antigen concentrations was counted as a positive reaction to that antigen.

\section{ANALYSIS OF RESULTS}

The frequency of yeasts at a given site was expressed as the percentage of patients positive, and the colony counts of yeasts were used to determine the geometric mean level of yeasts per patient. For precipitin tests the percentage frequencies of reactions against each antigen were determined. Percentage frequency data were compared by the $\chi^{2}$ test and colony count data by the Mann-Whitney $U$ test. In all cases, results were regarded as significant when the probability (P) that a given value of $\chi^{2}$ or $U$ was obtained by chance was less than 0.05 .

\section{Results}

The overall frequency of yeast pathogens among patients of all types on admission to hospital was: mouth $43 \%$ (of 254 patients); rectum $14 \%$ (of 243 patients); and vagina $17 \%$ (of 105 female patients).

Details of yeast species isolated are given in Table 3 . The distribution of yeast species from each sample site was similar in all groups of patients. $C$. albicans was the species most frequently recovered from the mouth, followed by $C$. glabrata (Table 3). The

Table 3 Frequency of recovery of yeast species from mouth, rectum, and vagina among surgical and nonsurgical patients

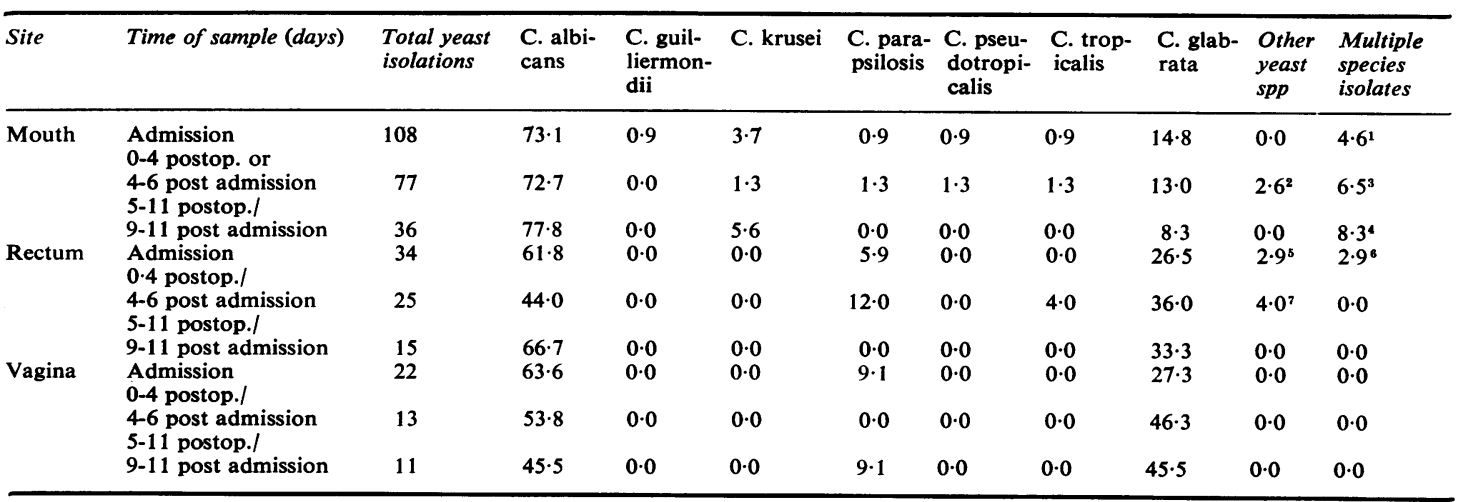

The number of isolates of each species is expressed as a percentage of total isolations from each site.

${ }^{1}$ C. albicans + C. krusei; C. albicans + C. glabrata (twice); C. krusei + C. glabrata; C. tropicalis + C. glabrata. ${ }^{2}$ Saccharomyces cerevisiae C. norvegensis. ${ }^{3}$ C. albicans $+C$. parapsilosis; C. albicans $+C$. glabrata; C. krusei + C. glabrata; C. pseudotropicalis + C. glabrata; C. tropicalis + C. glabrata. ${ }^{4}$ C. albicans + C. parapsilosis; C. albicans + C. parapsilosis; C. albicans $+C$. tropicalis; C. pseudotropicalis + C. glabrata. ${ }^{5}$ S. cerevisiae. ${ }^{\circ} \mathrm{C}$. albicans + C. glabrata. ${ }^{\circ} \mathrm{C}$. intermedia. 
prevalence of $C$. glabrata was higher in samples from the rectum or vagina, where it accounted for onethird of all isolates. Furthermore, there was an overall tendency towards higher recoveries of C. glabrata from the rectum and vagina in samples taken after admission, but this was the only change in yeast flora discernible between admission and postadmission samples (Table 3).

Among surgical patients, the percentage frequencies and quantities of yeasts from the mouth were highest in the group of antibiotic-treated patients (group 2), and the lowest were in the heart surgery group (group 3), who were receiving antifungals pre- and post-operatively, but this difference was not reflected in rectal and vaginal yeast isolations (Table 4). In each of the three groups of surgical patients there was usually a tendency for both the frequency and quantity of yeasts isolated from the mouth to rise postoperatively. This trend was seen most clearly in the open-heart surgery group where significant increases in both frequency and quantity of yeasts isolated in the 0-4 days post surgery period were followed by a drop from 5 to 11 days (the period of postoperative antifungal prophylaxis) with further increases from 12 to 35 days (when antifungals were discontinued). Similar but less pronounced postoperative increases in yeast isolations were seen in rectal and vaginal samples.

The frequency of yeasts isolated from the mouths of the group of surgical patients without factors predisposing to candidosis (group 1) and those treated with antibiotics (group 2) changed little during the postoperative period (Table 4), but an increase in frequency and quantity of yeast was apparent in postoperative rectal and vaginal samples. The increased frequencies were statistically significant in group 1 patients.

Yeast isolations among nonsurgical patients varied substantially within the subgroups (Table 5 ). In the majority of these patients the frequency and quantity of yeasts isolated from the mouth rose during their stay in hospital and was higher in those receiving antibiotic (group 5) or steroid (group 6) therapy than in those without factors said to predispose to yeast overgrowth (group 4). This trend was not reflected in yeast isolations from the vagina

Table 4 Frequencies of yeast recoveries from surgical patients

\begin{tabular}{|c|c|c|c|c|c|c|c|c|c|c|}
\hline \multirow[t]{2}{*}{ Patient group } & \multirow{2}{*}{$\begin{array}{l}\text { Sample time } \\
\text { (days) }\end{array}$} & \multicolumn{3}{|c|}{ Yeasts from mouth } & \multicolumn{3}{|c|}{ Yeasts from rectum } & \multicolumn{3}{|c|}{ Yeasts from vagina } \\
\hline & & $\begin{array}{l}\text { No. in } \\
\text { sample }\end{array}$ & $\%+v e$ & $\begin{array}{l}\text { Mean no. } \\
\text { colonies* }\end{array}$ & $\begin{array}{l}\text { No. in } \\
\text { sample }\end{array}$ & $\%+v e$ & $\begin{array}{l}\text { Mean no. } \\
\text { colonies }\end{array}$ & $\begin{array}{l}\text { No. in } \\
\text { sample }\end{array}$ & $\%+v e$ & $\begin{array}{l}\text { Mean no. } \\
\text { coloniest }\end{array}$ \\
\hline $\begin{array}{l}1 \\
\text { General } \\
\text { surgery only }\end{array}$ & $\begin{array}{l}\text { Admission } \\
0-4 \text { postop. } \\
5-11 \text { postop. }\end{array}$ & $\begin{array}{l}52 \\
42 \\
25\end{array}$ & $\begin{array}{l}42 \cdot 3 \\
47 \cdot 6 \\
36 \cdot 0\end{array}$ & $\begin{array}{l}0 \cdot 8 \\
1 \cdot 8 \\
0 \cdot 9\end{array}$ & $\begin{array}{l}51 \\
33 \\
25\end{array}$ & $\begin{array}{r}7 \cdot 8 \\
3 \cdot 0 \\
28 \cdot 0\end{array}$ & $\begin{array}{l}0 \cdot 2 \\
0 \cdot 1 \\
0 \cdot 5\end{array}$ & $\begin{array}{l}27 \\
22 \\
12\end{array}$ & $\begin{array}{r}3 \cdot 7 \\
13 \cdot 6 \\
25 \cdot 0\end{array}$ & $\begin{array}{l}0 \cdot 1 \\
0 \cdot 2 \\
0 \cdot 4\end{array}$ \\
\hline $\begin{array}{l}2 \\
\text { Surgery/ } \\
\text { antibiotic }\end{array}$ & $\begin{array}{l}\text { Admission } \\
0-4 \text { postop. } \\
5-11 \text { postop. }\end{array}$ & $\begin{array}{l}15 \\
12 \\
10\end{array}$ & $\begin{array}{l}60 \cdot 0 \\
58 \cdot 3 \\
50 \cdot 0\end{array}$ & $\begin{array}{l}3 \cdot 3 \\
0 \cdot 9 \\
3 \cdot 4\end{array}$ & $\begin{array}{r}15 \\
11 \\
9\end{array}$ & $\begin{array}{r}6 \cdot 7 \\
27 \cdot 3 \\
22 \cdot 2\end{array}$ & $\begin{array}{l}0 \cdot 1 \\
0 \cdot 3 \\
0 \cdot 3\end{array}$ & $\begin{array}{l}4 \\
4 \\
4\end{array}$ & $\begin{array}{r}0.0 \\
0.0 \\
25.0\end{array}$ & $\begin{array}{l}0 \cdot 1 \\
0 \cdot 1 \\
0 \cdot 8\end{array}$ \\
\hline $\begin{array}{l}3 \\
\text { Heart } \\
\text { surgery }\end{array}$ & $\begin{array}{l}\text { Admission } \\
\text { 0-4 postop. } \\
5-11 \text { postop. } \\
\text { 12-18 postop. } \\
\text { 19-25 postop. }\end{array}$ & $\begin{array}{l}44 \\
24 \\
29 \\
27 \\
21\end{array}$ & $\begin{array}{l}27 \cdot 3 \\
37 \cdot 5 \\
20 \cdot 7 \\
33 \cdot 3 \\
47 \cdot 7\end{array}$ & $\begin{array}{l}0 \cdot 4 \\
2 \cdot 4 \\
0 \cdot 3 \\
0 \cdot 6 \\
1 \cdot 6\end{array}$ & $\begin{array}{l}44 \\
22 \\
29 \\
26 \\
21\end{array}$ & $\begin{array}{r}11 \cdot 4 \\
13 \cdot 6 \\
3 \cdot 4 \\
15 \cdot 3 \\
23 \cdot 8\end{array}$ & $\begin{array}{l}0 \cdot 1 \\
0 \cdot 2 \\
0 \cdot 1 \\
0 \cdot 3 \\
0 \cdot 3\end{array}$ & $\begin{array}{l}20 \\
10 \\
13 \\
12 \\
10\end{array}$ & $\begin{array}{r}5 \cdot 0 \\
10 \cdot 0 \\
30 \cdot 8 \\
16 \cdot 7 \\
10 \cdot 0\end{array}$ & $\begin{array}{l}0 \cdot 1 \\
0 \cdot 3 \\
0 \cdot 1 \\
0 \cdot 5 \\
0 \cdot 2\end{array}$ \\
\hline
\end{tabular}

*Geometric mean no. colonies per $0.1 \mathrm{ml}$ mouth wash fluid.

†Geometric mean colony count per plate.

Table 5 Frequencies of yeast recoveries from nonsurgical patients

\begin{tabular}{|c|c|c|c|c|c|c|c|c|c|c|}
\hline \multirow[t]{2}{*}{ Patient group } & \multirow{2}{*}{$\begin{array}{l}\text { Sample time } \\
\text { (days) }\end{array}$} & \multicolumn{3}{|c|}{ Yeasts from mouth } & \multicolumn{3}{|c|}{ Yeasts from rectum } & \multicolumn{3}{|c|}{ Yeasts from vagina } \\
\hline & & $\begin{array}{l}\text { No. in } \\
\text { sample }\end{array}$ & $\%+v e$ & $\begin{array}{l}\text { Mean no. } \\
\text { colonies* }\end{array}$ & $\begin{array}{l}\text { No. in } \\
\text { sample }\end{array}$ & $\%+v e$ & $\begin{array}{l}\text { Mean no. } \\
\text { colonies } \dagger\end{array}$ & $\begin{array}{l}\text { No. in } \\
\text { sample }\end{array}$ & $\%+v e$ & $\begin{array}{l}\text { Mean no. } \\
\text { colonies } \dagger\end{array}$ \\
\hline $\begin{array}{l}4 \\
\text { General } \\
\text { medical }\end{array}$ & $\begin{array}{l}\text { Admission } \\
\text { 4-6 postop. } \\
\text { 9-11 postop. }\end{array}$ & $\begin{array}{l}59 \\
35 \\
13\end{array}$ & $\begin{array}{l}33 \cdot 9 \\
34 \cdot 3 \\
53 \cdot 8\end{array}$ & $\begin{array}{l}0 \cdot 7 \\
0 \cdot 6 \\
2 \cdot 6\end{array}$ & $\begin{array}{l}56 \\
32 \\
12\end{array}$ & $\begin{array}{r}7 \cdot 1 \\
25 \cdot 0 \\
16 \cdot 7\end{array}$ & $\begin{array}{l}0 \cdot 2 \\
0 \cdot 3 \\
0 \cdot 2\end{array}$ & $\begin{array}{l}23 \\
14\end{array}$ & $\begin{array}{r}17 \cdot 4 \\
7 \cdot 1\end{array}$ & $\begin{array}{l}0 \cdot 2 \\
0 \cdot 1\end{array}$ \\
\hline $\begin{array}{l}5 \\
\text { Antibiotics }\end{array}$ & $\begin{array}{l}\text { Admission } \\
\text { 4-6 postop. }\end{array}$ & $\begin{array}{l}33 \\
20\end{array}$ & $\begin{array}{l}39 \cdot 4 \\
55 \cdot 0\end{array}$ & $\begin{array}{l}2 \cdot 0 \\
2 \cdot 9\end{array}$ & $\begin{array}{l}32 \\
18\end{array}$ & $\begin{array}{l}25 \cdot 0 \\
27 \cdot 8\end{array}$ & $\begin{array}{l}0.4 \\
0.8\end{array}$ & $\begin{array}{l}14 \\
10\end{array}$ & $\begin{array}{l}42 \cdot 9 \\
40 \cdot 0\end{array}$ & $\begin{array}{l}1 \cdot 5 \\
1 \cdot 7\end{array}$ \\
\hline $\begin{array}{l}6 \\
\text { Steroids }\end{array}$ & $\begin{array}{l}\text { Admission } \\
\text { 4-6 postop. }\end{array}$ & $\begin{array}{r}19 \\
8\end{array}$ & $\begin{array}{l}52 \cdot 6 \\
62 \cdot 5\end{array}$ & $\begin{array}{l}2 \cdot 6 \\
5 \cdot 4\end{array}$ & $\begin{array}{r}18 \\
8\end{array}$ & $\begin{array}{l}33 \cdot 3 \\
12 \cdot 5\end{array}$ & $\begin{array}{l}0 \cdot 4 \\
0 \cdot 1\end{array}$ & 7 & $14 \cdot 3$ & $0 \cdot 2$ \\
\hline $\begin{array}{l}7 \\
\text { Diabetics }\end{array}$ & $\begin{array}{l}\text { Admission } \\
\text { 4-6 postop. } \\
\text { 9-11 postop. }\end{array}$ & $\begin{array}{l}32 \\
24 \\
15\end{array}$ & $\begin{array}{l}68 \cdot 8 \\
54 \cdot 2 \\
40 \cdot 0\end{array}$ & $\begin{array}{l}5 \cdot 5 \\
1 \cdot 2 \\
0 \cdot 5\end{array}$ & $\begin{array}{l}27 \\
23 \\
15\end{array}$ & $\begin{array}{l}25 \cdot 9 \\
17 \cdot 4 \\
13 \cdot 3\end{array}$ & $\begin{array}{l}0 \cdot 4 \\
0 \cdot 3 \\
0 \cdot 3\end{array}$ & $\begin{array}{r}10 \\
8 \\
6\end{array}$ & $\begin{array}{l}60 \cdot 0 \\
50 \cdot 0 \\
33 \cdot 3\end{array}$ & $\begin{array}{l}6 \cdot 7 \\
2 \cdot 3 \\
1 \cdot 6\end{array}$ \\
\hline
\end{tabular}

* Geometric mean no. colonies per $0.1 \mathrm{ml}$ mouth wash fluid.

+ Geometric mean colony count per plate. 
and rectum, where the figures showed no significant changes at the different sample periods. The highest frequency and quantity of yeasts on admission were found in the group of diabetic patients (group 7). By contrast, the data for this group indicated a steady fall in yeast colonisation at all sites over the period of hospitalisation.

Tests for precipitating antibodies to yeast antigens among the patient groups revealed an increase in frequency during the periods of hospitalisation. Of 217 sera obtained within 24 hours of patients' admission, $47 \%$ reacted with $C$. albicans culture filtrate antigens, $11 \%$ with $C$. albicans cytoplasmic extract, $6 \%$ with $C$. parapsilosis cytoplasmic extract, and $14 \%$ with $C$. albicans mannan. The corresponding data for sera taken 5 to 11 days after surgery (surgical patients) or admission (nonsurgical patients) were $67 \%, 35 \%, 28 \%$, and $48 \%$, respectively.

The overall pattern of increase was most marked among the three groups of surgical patients (Table 6) where the frequencies of candida precipitins to all four antigens were increased significantly after surgery except for precipitins to $C$. albicans culture filtrate and cytoplasmic extract in the group of antibiotic-treated patients (group 2), though even in these cases a considerable increase in frequency, albeit statistically insignificant, was apparent.

Among nonsurgical patients the rise in frequency of precipitins was less dramatic (Table 7). In the patients without additional predisposing factors (group 4), precipitins to the two cytoplasmic extracts were detected more often 9 to 11 days after admission, but no increase was seen in the frequency of precipi- tins to filtrate and mannan antigens of $C$. albicans. The number of patients sampled 9 to 11 days after admission in the steroid-treated group (group 6) was too small to allow analysis. None of the increases in detectable precipitins among the diabetics (group 7) were significant, but there was a significant rise in the frequency of precipitins to all antigens except $C$. albicans culture filtrate among the antibiotic-treated patients (group 5).

\section{Discussion}

Although none of the patients included in this study showed signs or symptoms of superficial or deepseated candidosis, many were found to harbour large numbers of potentially pathogenic yeasts.

The frequency of yeasts among the patients on admission to hospital compares well with previously published data on hospital patients. The high proportion of $C$. albicans isolates from the mouth and the lower frequency of this species in rectal and vaginal samples also agrees well with previous surveys of yeast flora among hospital patients. ${ }^{2}$ The frequency of the carriage of yeasts increased during their period in hospital, and this is consistent with the findings of Stone et al. ${ }^{5}$ The debilitative effects of illness in general and of surgery in particular predispose patients to overgrowth of yeasts in the gut. The overgrowth was more marked among patients whose treatment or illness was of a kind known to predispose to candidosis. ${ }^{2}$ In the case of surgical patients, the overgrowth occurred in the immediate postoperative period, whereas in non-

Table 6 Precipitin test results-surgical patients

\begin{tabular}{|c|c|c|c|c|c|c|}
\hline Patient group & Sample time & No. in sample & $\begin{array}{l}\text { C. albicans } \\
\text { filtrate } \%+v e\end{array}$ & $\begin{array}{l}\text { C. albicans } \\
\text { cytoplasm } \%+v e\end{array}$ & $\begin{array}{l}\text { C. albicans } \\
\text { mannan } \%+v e\end{array}$ & $\begin{array}{l}\text { C. parapsilosis } \\
\text { cytoplasm } \%+v e\end{array}$ \\
\hline $\begin{array}{l}1 \text { General } \\
\text { surgery only }\end{array}$ & $\begin{array}{l}\text { Admission } \\
\text { 5-11 days postop. }\end{array}$ & $\begin{array}{l}41 \\
23\end{array}$ & $\begin{array}{l}24 \\
65\end{array}$ & $\begin{array}{r}5 \\
35\end{array}$ & $\begin{array}{l}15 \\
39\end{array}$ & $\begin{array}{r}5 \\
26\end{array}$ \\
\hline $\begin{array}{l}2 \text { Surgery/ } \\
\text { antibiotics }\end{array}$ & $\begin{array}{l}\text { Admission } \\
\text { 5-11 days postop. }\end{array}$ & $\begin{array}{r}11 \\
7\end{array}$ & $\begin{array}{l}64 \\
86\end{array}$ & $\begin{array}{l}18 \\
57\end{array}$ & $\begin{array}{l}18 \\
86\end{array}$ & $\begin{array}{r}9 \\
57\end{array}$ \\
\hline $\begin{array}{l}3 \\
\text { Heart surgery }\end{array}$ & $\begin{array}{l}\text { Admission } \\
5-11 \text { days postop. } \\
\text { 12-18 days postop. } \\
\text { 19-25 days postop. }\end{array}$ & $\begin{array}{l}35 \\
24 \\
22 \\
20\end{array}$ & $\begin{array}{r}60 \\
71 \\
100 \\
95\end{array}$ & $\begin{array}{r}9 \\
42 \\
55 \\
55\end{array}$ & $\begin{array}{l}20 \\
79 \\
77 \\
80\end{array}$ & $\begin{array}{r}3 \\
42 \\
45 \\
50\end{array}$ \\
\hline
\end{tabular}

Table 7 Precipitin test results-nonsurgical patients

\begin{tabular}{|c|c|c|c|c|c|c|}
\hline Patient group & Sample time & No. in sample & $\begin{array}{l}\text { C. albicans } \\
\text { filtrate } \%+v e\end{array}$ & $\begin{array}{l}\text { C. albicans } \\
\text { cytoplasm } \%+v e\end{array}$ & $\begin{array}{l}\text { C. albicans } \\
\text { mannan } \%+v e\end{array}$ & $\begin{array}{l}\text { C. parapsilosis } \\
\text { cytoplasm } \%+v e\end{array}$ \\
\hline$\stackrel{4}{\text { General medical }}$ & $\begin{array}{l}\text { Admission } \\
9-11 \text { days }\end{array}$ & $\begin{array}{l}27 \\
10\end{array}$ & $\begin{array}{l}41 \\
40\end{array}$ & $\begin{array}{l}11 \\
20\end{array}$ & $\begin{array}{l}14 \\
10\end{array}$ & $\begin{array}{r}4 \\
10\end{array}$ \\
\hline 5 & $\begin{array}{l}\text { Admission } \\
9-11 \text { days }\end{array}$ & $\begin{array}{r}29 \\
4\end{array}$ & $\begin{array}{r}62 \\
100\end{array}$ & $\begin{array}{l}14 \\
50\end{array}$ & $\begin{array}{l}17 \\
75\end{array}$ & $\begin{array}{r}7 \\
50\end{array}$ \\
\hline $\begin{array}{l}6 \\
\text { Steroids }\end{array}$ & $\begin{array}{l}\text { Admission } \\
9-11 \text { days }\end{array}$ & $\begin{array}{r}17 \\
4\end{array}$ & $\begin{array}{l}53 \\
75\end{array}$ & $\begin{array}{r}12 \\
0\end{array}$ & $\begin{array}{l}12 \\
25\end{array}$ & $\begin{array}{l}0 \\
0\end{array}$ \\
\hline $\begin{array}{l}7 \\
\text { Diabetics }\end{array}$ & $\begin{array}{l}\text { Admission } \\
\text { 9-11 days }\end{array}$ & $\begin{array}{l}30 \\
13\end{array}$ & $\begin{array}{l}43 \\
62\end{array}$ & $\begin{array}{l}13 \\
31\end{array}$ & $\begin{array}{l}13 \\
15\end{array}$ & $\begin{array}{r}13 \\
8\end{array}$ \\
\hline
\end{tabular}


surgical patients the effect was more extended and less acute. The data on yeast isolations from diabetic patients indicate that yeast overgrowth probably occurred during the acute diabetic episode that led to their admission to hospital, and that yeast levels fell when the diabetes was stabilised.

It is clear that precipitating antibodies to candida extracts occur frequently among all types of hospital patients in the absence of overt candidosis. The results obtained corroborate and extend previous reports of the occurrences of candida antibodies in the absence of disease. It is notable that in this study the appearance of candida precipitins was preceded in most groups of patients by an increase in frequency and quantity of yeasts isolated from the mouth. These antibodies are likely, therefore, to result from yeast overgrowth, which is sufficient to cause a transient candidaemia as a result of passage of yeast cells across the gut wall into the bloodstream by a persorption mechanism. ${ }^{8} 2024$ It may well be that the appearance of precipitins to candida cytoplasmic extracts is a more sensitive indicator of yeast colonisation or of subclinical candidaemia than is direct isolation of the fungus at the time of the episode.

Efforts have recently been directed towards increasing the specificity of the precipitin tests for candidosis. The cell wall mannan, inevitably found in cytoplasmic extracts of candida, is considered by some workers ${ }^{25}$ to be the component responsible for the majority of positive precipitin reactions in uninfected individuals, whereas those with a candida infection show an additional reaction to the protein component of the extract. Indeed, a crossed immunoelectrophoresis method which allows differentiation of the mannan and protein/glycoprotein reactions has been found to increase greatly the predictive value of the precipitin test. ${ }^{26}$ It was clear that our C. albicans cytoplasmic extract contained some mannan since lines of identity were occasionally noted, in double diffusion plates, between cytoplasmic extract and purified mannan. However, in this study by no means all of the positive precipitin reactions were to polysaccharide candida antigens. Although such reactions occurred frequently, in two groups of patients the frequency of precipitins to the cytoplasmic extract of $C$. albicans was higher than to $C$. albicans mannan, and, moreover, many patients reacted with the cytoplasmic extract to give several precipitin lines in the test. Differentiation of polysaccharide and protein/glycoprotein reactions does not, therefore, per se distinguish yeast overgrowth and transient or subclinical candidosis from true deep-seated infection.

Diagnostic interpretation of the candida precipitin test should include consideration of the length of time for which a patient has been in hospital, and any treatment given which may have predisposed the patient to yeast overgrowth. Despite its shortcomings, the precipitin test remains a valuable aid to diagnosis of systemic candidosis. A single positive test result has little or no diagnostic significance, although a high precipitin titre may suggest infection. The test is most useful when performed regularly over a period of time, with the precipitin titre estimated on each occasion. Except in immunosuppressed or anergic patients, only consistently rising levels of candida antibodies are likely to indicate deep-seated infection.

We thank Mr MI Ionescu, Mr EA Benson, Mr FG Smiddy, and Professor GP McNicol for their cooperation and for permission to approach their patients to participate in this study. We are grateful also to Mrs J O'Malley for technical assistance, to Mr RA Forster for his help, and to the Leeds Area Health Authority (Teaching) for financial support.

\section{References}

${ }^{1}$ Winner HI, Hurley R. Candida albicans. London: Churchill, 1964.

${ }^{2}$ Odds FC. Candida and Candidosis. Leicester: Leicester University Press, 1979.

${ }^{3}$ Marks MI, Marks S, Brazeau M. Yeast colonization in hospitalized and nonhospitalized children. J Pediatr 1975;87:524-7.

${ }^{4}$ Somerville DA. Yeasts in a hospital for patients with skin diseases. J Hyg 1972;70:667-75.

${ }^{5}$ Stone HH, Geheber CE, Kolb LD, Kitchens WR. Alimentary tract colonization by Candida albicans. J Surg Res 1973;14:273-6.

${ }^{6}$ Seelig MS. Mechanisms by which antibiotics increase the incidence and severity of candidiasis and alter the immunological defences. Bacteriol Rev 1966;30:442-59.

${ }^{7}$ Berdon JK, Seita CL. The incidence of Candida albicans in hospital patients. J Oral Med 1971;26:123-6.

${ }^{8}$ Stone HH, Kolb LD, Currie CA, Geheber CE, Cuzzell JZ. Candida sepsis: pathogenesis and principles of treatment. Ann Surg 1974;179:697-711.

9 Taschdjian CL, Seelig MS, Kozinn PJ. Serological diagnosis of candidal infections. CRC Crit Rev Clin Lab Sci $1973 ; 4: 19-59$.

10 Pepys JM, Faux JA, Longbottom JL, McCarthy DS, Hargreave FE. Candida albicans precipitins in respiratory disease in man. $J$ Allergy $1968 ; 41: 305-18$.

${ }^{11}$ Stanley VC, Hurley R, Carroll CJ. Distribution and significance of Candida precipitins in sera from pregnant women. J Med Microbiol 1972;5:313-20.

12 Douchet C, Müller J. Valeur et limites de la sérologie du Candida albicans. Lyon Med 1972;227:1129-33.

13 Jones DR, Warnock DW. Observations on the use of the double diffusion test in the diagnosis of vaginal candidiasis. J Clin Pathol 1977;30:262-5.

14 Holder IA, Kozinn PJ, Law EJ. Evaluation of Candida precipitin and agglutinin tests for the diagnosis of systemic candidiasis in burn patients. J Clin Microbiol $1977 ; 6: 219-23$

${ }^{15}$ Filice G, Yu B, Armstrong D. Immunodiffusion and agglutination tests for Candida in patients with neoplastic 
disease: inconsistent correlation of results with invasive infections. J Infect Dis 1977;135:349-57.

16 Murray IG, Buckley HR, Turner GC. Serological evidence of Candida infection after open-heart surgery. $J$ Med Microbiol 1969;2:463-9.

${ }^{17}$ Bacon PA, Davidson C, Smith B. Antibodies to Candida and autoantibodies in sub-acute bacterial endocarditis. $Q J$ Med 1974;43:537-50.

18 Parsons ER, Nassau E. Candida serology in open-heart surgery. J Med Microbiol 1974;7:415-23.

10 Lehner T, Buckley HR, Murray IG. The relationship between fluorescent, agglutinating, and precipitating antibodies to Candida albicans and their immunoglobulin classes. J Clin Pathol 1972;25:344-8.

${ }^{20}$ Evans EGV, Forster RA. Antibodies to Candida after operations on the heart. J Med Microbiol 1976;9:303-8.

${ }^{21}$ Taschdjian CL, Burchall JJ, Kozinn PJ. Rapid identification of Candida albicans by filamentation on serum and serum substitutes. Am J Dis Child 1960;99:212-5.

22 Lodder J. The Yeasts: a Taxonomic Study. Amsterdam:
North Holland Co., 1970.

23 Odds FC, Evans EGV, Holland KT. Detection of Candida precipitins. A comparison of double diffusion and counter immunoelectrophoresis. J Immunol Methods 1975;7:211-8.

${ }^{24}$ Krause W, Matheis $H$, Wulf $K$. Fungaemia and funguria after oral administration of Candida albicans. Lancet 1969;1:598-9.

${ }^{25}$ Syverson RE, Buckley HR. Cell wall antigens in soluble cytoplasmic extracts of Candida albicans as demonstrated by crossed immuno-affinoelectrophoresis with concanavalin A. J Immunol Methods 1977;18:149-56.

${ }^{26}$ Syverson RE, Buckley HR, Gibian JR. Increasing the predictive value positive of the precipitin test for the diagnosis of deep-seated candidiasis. Am J Clin Pathol $1978 ; 70: 826-31$.

Requests for reprints to: Dr FC Odds, Department of Microbiology, University of Leicester, University Road, Leicester LE1 7RH, UK. 